\title{
Calcium waves
}

\author{
Lionel F. Jaffe* \\ The Marine Biological Laboratory, 7 MBL Street, Woods Hole, MA 02543, USA
}

\begin{abstract}
Waves through living systems are best characterized by their speeds at $20^{\circ} \mathrm{C}$. These speeds vary from those of calcium action potentials to those of ultraslow ones which move at 1-10 and/or $10-20 \mathrm{~nm} \mathrm{~s}^{-1}$. All such waves are known or inferred to be calcium waves. The two classes of calcium waves which include ones with important morphogenetic effects are slow waves that move at $0.2-2 \mu \mathrm{m} \mathrm{s}^{-1}$ and ultraslow ones. Both may be propagated by cycles in which the entry of calcium through the plasma membrane induces subsurface contraction. This contraction opens nearby stretch-sensitive calcium channels. Calcium entry through these channels propagates the calcium wave. Many slow waves are seen as waves of indentation. Some are considered to act via cellular peristalsis; for example, those which seem to drive the germ plasm to the vegetal pole of the Xenopus egg. Other good examples of morphogenetic slow waves are ones through fertilizing maize eggs, through developing barnacle eggs and through axolotl embryos during neural induction. Good examples of ultraslow morphogenetic waves are ones during inversion in developing Volvox embryos and across developing Drosophila eye discs. Morphogenetic waves may be best pursued by imaging their calcium with aequorins.
\end{abstract}

Keywords: calcium waves; morphogenesis; stretch-sensitive channels; peristalsis; aequorin

\section{INTRODUCTION}

Calcium waves were discovered as the wave of elevated free cytosolic calcium which traverses medaka fish eggs during fertilization (Gilkey et al. 1978; figure 1). This wave moves at approximately $10 \mu \mathrm{m} \mathrm{s}^{-1}$ as do all fertilization waves when corrected for temperature. Fertilization waves, in turn, are part of the group of calcium waves called fast ones that move at $10-30 \mu \mathrm{m} \mathrm{s}^{-1}$ through cells (Jaffe 2002) and are propagated along endoplasmic reticula to bring about 'calcium-induced calcium release' from its interior (Jaffe 1991). Fast calcium waves, in turn, are one of 4-5 groups of calcium waves when these are arranged by propagation speed (figure 2 ).

Since this paper is based on a lecture given at a recent Royal Society meeting on 'Calcium signals and developmental patterning', the main focus will be on slow and ultraslow calcium waves, the only groups that much effect such patterning. All speeds are corrected for temperature via Cosens et al. (1976). According to Cosens et al., transport speeds fell by nearly fivefold as the temperature fell from 38 to $20^{\circ} \mathrm{C}$ and nearly doubled when the temperature rose from 14 to $20^{\circ} \mathrm{C}$-a clear indicator that temperature corrections are needed. This could surely be improved by using reports of temperature dependence that are appropriate for the particular process considered rather than a single one; however, time does not allow this now. More important, it should be emphasized that many papers do not mention speeds in the text; in these papers, speeds were obtained from images of the

\section{*ljaffe@mbl.edu}

One contribution of 11 to a Discussion Meeting Issue 'Calcium signals and developmental patterning'. process involved. For example, the speed of the indentation wave along barnacle eggs was obtained from the length and time data shown in figure 1 of Lewis et al. (1973).

\section{SLOW CALCIUM WAVES}

Table 1 shows a list of 28 cases of slow waves which were selected from approximately 60 reports by listing only what seem to be the most reliable ones in those cases where measurements of essentially the same wave speed were reported in different papers. Seven of these were directly seen to be calcium waves while in the eighth (no. 13 that accompanies the fertilization of maize eggs) a $1 \mu \mathrm{m} \mathrm{s}^{-1}$ wave of calcium influx was observed. The fertilization wave through maize eggs is of special interest since it travels far more slowly than those through animal eggs. This may have evolved since the equivalent of polyspermy cannot occur in maize eggs which would allow the evolution of a slower and perhaps less expensive mechanism.

More important, this list confirms that calcium waves that move at $0.2-2 \mu \mathrm{m} \mathrm{s}^{-1}$ form a natural group as was proposed by Jaffe \& Créton (1998) and is shown in figure 2, while figures 3-5 show three examples of such slow waves, namely ones through maize eggs during fertilization, through postfertilization barnacle eggs and through axolotl embryos during neural induction.

Proposed mechanisms for the propagation of slow intracellular and intercellular calcium waves are shown in figures 6 and 7, respectively. The proposed intracellular mechanism may be thought to start with the entry of calcium ions through a stretch-sensitive channel. The resultant rise in the concentration of subsurface calcium induces the contraction of 

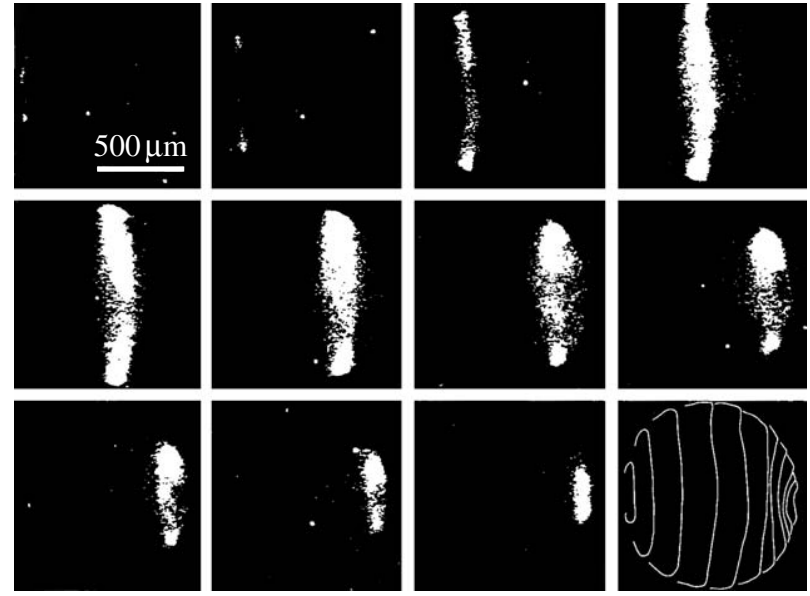

Figure 1. A calcium wave through a fertilizing medaka egg. Adapted from Gilkey et al. (1978, fig. 2a).

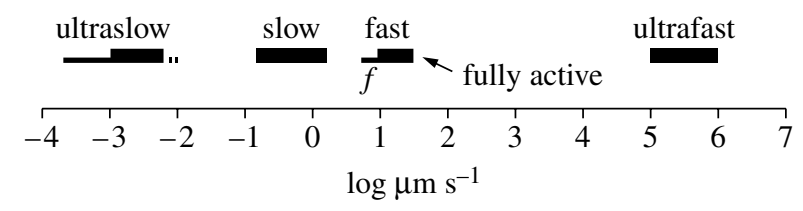

Figure 2. The speeds of groups of calcium waves: $f$ means fertilization. Modified from Jaffe \& Créton (1998, fig. 2).

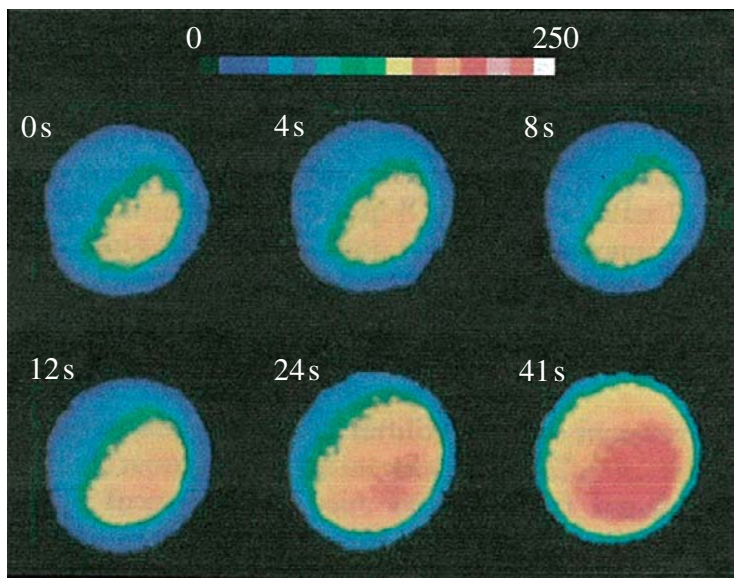

Figure 3. A calcium wave through a fertilizing maize egg. Adapted from Digonnet et al. (1997, fig. 3A).

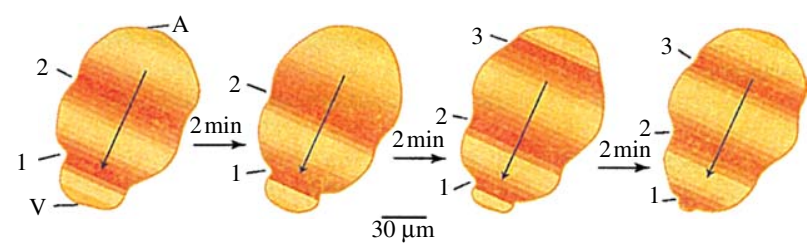

Figure 4. A 'peristaltic' postfertilization wave through a barnacle egg: A, animal pole; V, vegetal pole. Adapted from Jaffe (1999, fig. 6B).

actinomyosin filaments similar to those induced to contract by calcium increases in muscle cells. This contraction relays the calcium wave by opening nearby stretch-sensitive calcium channels. These then let in calcium to propagate the cycle. The proposed mechanism for intercellular calcium waves inserts a
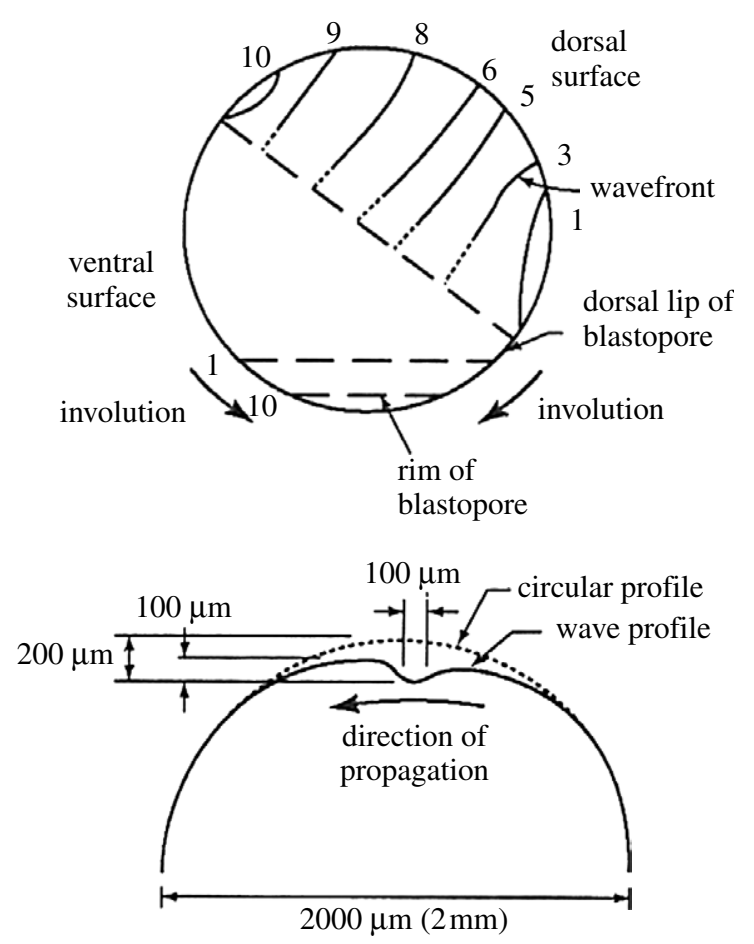

Figure 5. A wave across an axolotl embryo during neurulation. Adapted from Jaffe (1999, fig. 6C).

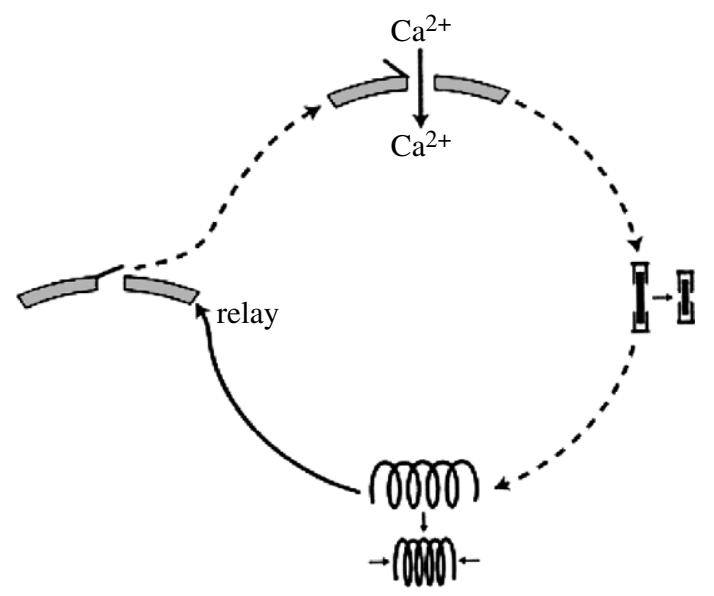

Figure 6. A proposed mechanism for the propagation of slow intracellular calcium waves.

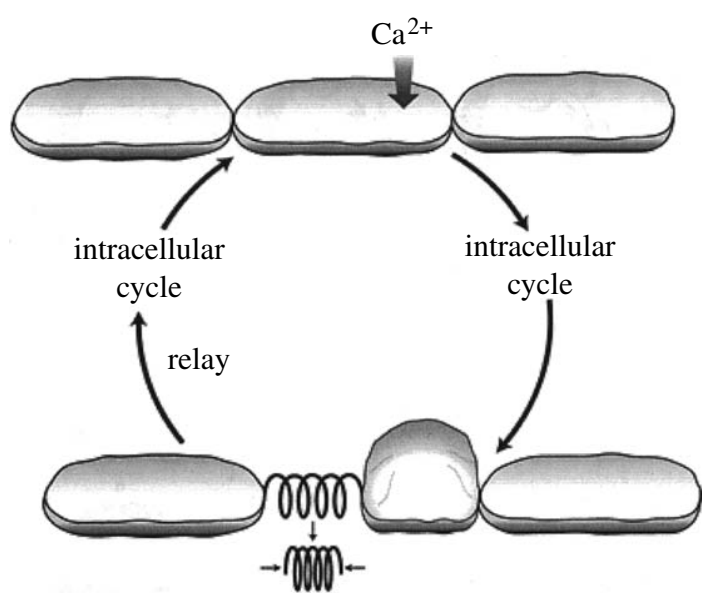

Figure 7. A proposed mechanism for the propagation of slow intercellular calcium waves. 
Table 1. A selected list of speeds of slow waves.

\begin{tabular}{|c|c|c|c|}
\hline no. & system & indicator & speed $\left(\mu \mathrm{m} \mathrm{s}^{-1}\right)$ \\
\hline \multicolumn{4}{|l|}{ eggs } \\
\hline 1 & Beröe (Ctenophore; Houliston et al. 1993) & 'peristaltic' indentation & $\sim 0.2$ \\
\hline 2 & leech (Fernandez et al. 1990) & indentation & 1.0 \\
\hline 3 & barnacle (Lewis et al. 1973; fig. 4B) & indentation & 0.4 \\
\hline 4 & cricket (Vollmar 1972) & 'peristaltic' indentation & 0.4 \\
\hline 5 & gall midge (Wolf 1985) & particle saltation & 0.3 \\
\hline 6 & ascidian (Sardet et al. 1989) & indentation & 1.4 \\
\hline 7 & medaka fish (Fluck et al. 1991) & calcium and indentation & 1.5 \\
\hline 8 & zebrafish (Créton et al. 1998) & calcium via aequorin & 0.5 \\
\hline 9 & Xenopus (Savage \& Danilchik 1993) & 'peristaltic' indentation & 0.5 \\
\hline 10 & toad (Dan 1960) & indentation & 0.6 \\
\hline 11 & newt (Selman \& Waddington 1955$)$ & indentation & 1.4 \\
\hline 12 & Xenopus (Muto et al. 1996) & calcium and indentation & 1.8 \\
\hline 13 & maize (Antoine et al. 2000, fig. 3) & calcium influx & 1.1 \\
\hline \multicolumn{4}{|c|}{ later in development } \\
\hline 14 & weevil (Miyamoto \& van der Meer 1982) & yolk contraction & 0.2 \\
\hline 15 & blowfly (Agrell 1962) & mitosis & 0.8 \\
\hline 16 & Drosophila (Foe \& Alberts 1983) & mitosis & 0.4 \\
\hline 17 & Drosophila (Kam et al. 1991) & ingression & 0.2 \\
\hline 18 & medaka's stellate layer (Simon \& Cooper 1995) & calcium & 0.3 \\
\hline 19 & chick embryo (Stern \& Goodwin 1977) & cell movement & 0.7 \\
\hline \multirow[t]{3}{*}{20} & chick embryo (Robertson 1979) & cell movement & \\
\hline & parallel to somites & refractive index & 0.7 \\
\hline & perpendicular to somites & refractive index & 0.3 \\
\hline \multicolumn{4}{|c|}{ other } \\
\hline 21 & Dictyostelium's mound formation (Rietdorf et al. 1996) & optical density $^{\mathrm{a}}$ & 1.1 \\
\hline 22 & Dictyostelium's slug (Dormann \& Weijer 2001) & optical density ${ }^{\mathrm{a}}$ & 0.7 \\
\hline 23 & isolated Dictyostelium cells (Bretschneider et al. 2004) & actin polymerization & 0.7 \\
\hline 24 & two-dimensional Dictyostelium slugs ${ }^{\mathrm{b}}$ (Rieu et al. 2004) & autofluorescence & 1.0 \\
\hline 25 & hydroid polyps (Beloussov et al. 1989) & cell reorientation & 1.0 \\
\hline 27 & moss filaments (Tucker et al. 2005) & calcium & 2.0 \\
\hline 28 & lily pollen (Malhó \& Trewavas 1996 ) & calcium & 0.6 \\
\hline
\end{tabular}

${ }^{a}$ It was argued by Jaffe (1997) that these waves of optical density are the ones of surface cell contraction which would stretch surface cells (and hence their membranes) in nearby zones along the direction of wave movement.

b These two-dimensional slugs are one cell thick, yet behave like natural slugs that are many cells thick (Bonner 1998).

new step in each cycle in which a wave through one cell induces it to round up and in this way tug on and stretch the nearest stretch-sensitive channels in adjacent cells. It has been suggested that waves of such changes in cell shape accompany optical density waves along Dictyostelium slugs (Jaffe 1997). This conjecture was based upon the facts that postaggregation cells in Dictyostelium rounded up or 'cringed' soon after cyclic AMP was applied to them (Futrelle et al. 1982) and that cyclic AMP waves are believed to accompany optical density waves in Dictyostelium slugs (Dormann \& Weijer 2001).

One important function of slow waves may be to drive materials towards one pole of a cell via peristalsis and this process is shown in figure 8. Cases in which this is believed to occur are listed in table 1 . These include case no. 1 (that of Beröe eggs), case no. 4 (that of cricket eggs) and case no. 9 (that of Xenopus embryos).

\section{ULTRASLOW WAVES}

A list of ultraslow waves that may be morphogenetic is shown in table 2 . While calcium has never been imaged during an ultraslow wave, one can infer from the following evidence that they are calcium waves and that

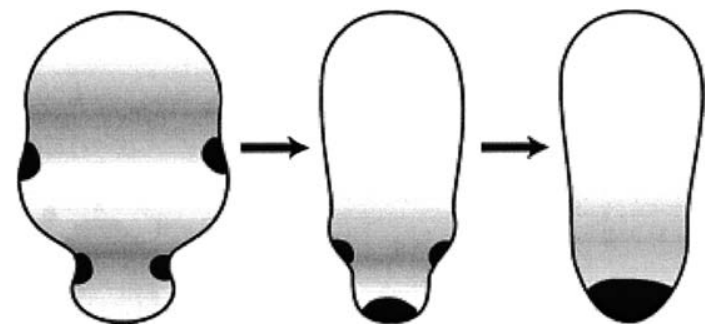

Figure 8. Diagrammatic representation of how cell peristalsis can drive intracellular material towards one pole of a cell.

they are driven by the same mechanisms that propagate slow waves.

Re. the inversion of developing Volvox embryos (figure 9), Kelland (1977) pointed out that this process involves a wave of contraction of almost all of its cells at their basal ends. Since localized contraction is well known to be effected by increases in calcium which act on actomyosin, this old observation alone strongly suggests that inversion is effected by a calcium wave. Moreover, actomyosin inhibitors were found to inhibit inversion (Nishii \& Ogihara 1999), and Nishii et al. (2003) showed that a particular kinesin is needed for inversion while others have shown that calcium regulates some kinesins. 

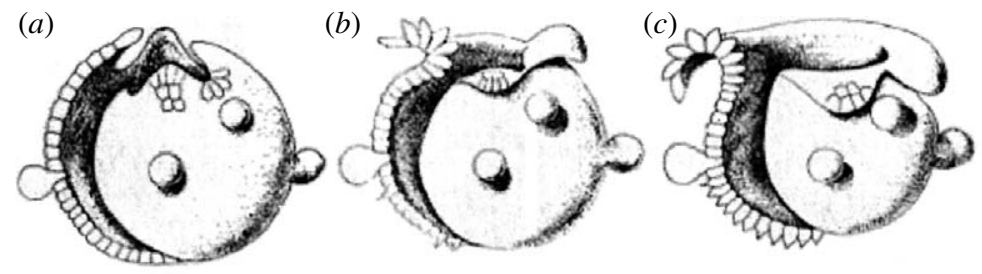

(d)
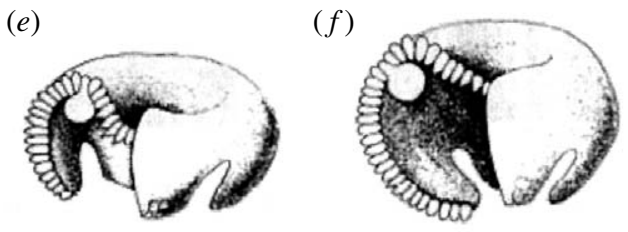

$(g)$
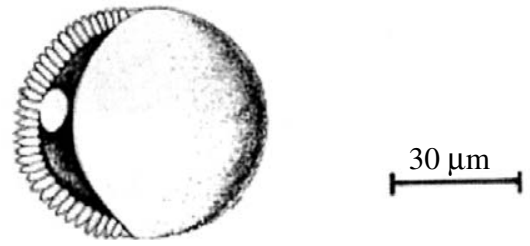

Figure 9. Inversion of developing Volvox embryos. Adapted from Kelland (1977, fig. 2).

Re. the ultraslow waves of furrowing seen in developing Drosophila eye discs (figure 10) and in developing amphibian embryos: waves of furrowing are waves of indentation during cell division and 10 of the cases of slow waves listed in table 1 are seen as indentation waves.

Re. the DNA replication waves seen in the Euplotes macronucleus (figure 11): isolated macronuclei of Euplotes are reported to reversibly and grossly contract as calcium is raised in the physiological range (Arikawa et al. 2003). This surprising finding suggests the possibility of an ultraslow calcium wave deep within a cell.

Re. the waves of growth cone formation or 'sprouting' along embryonic hippocampal neurons (figure 12): Tam \& Gordon (2003) have reviewed evidence in the neuromuscular junction that an influx of calcium ions is needed for sprouting.

\section{CONCLUSIONS}

The main conclusions are the following:

(i) the first thing that one should know about a wave is its speed,

(ii) all waves are known or inferred to be calcium waves,

(iii) slow and ultraslow calcium waves are the most important ones for pattern generation, and

(iv) slow and ultraslow calcium waves may be mechanically propagated by travelling cycles that involve stretch-activated calcium channels.

The pursuit of calcium waves most needs investigations of calcium patterns within waves, and this would be best done with the luminescent aequorins rather with fluorescent calcium indicators. The advantages of imaging calcium patterns with aequorins are presented in Créton et al. (1999) and include: imaging with aequorins is not disturbed by the exciting light that is needed to use fluorescent indicators; it allows continuous recording for periods of more than a day; it provides quantifiable output over the whole physiological range of calcium concentrations. Aequorins (or really apoaequorins) can be introduced by transfection as well as injection. This allows study throughout the organism's life as well as those of its female progeny. Moreover, slow and ultraslow waves

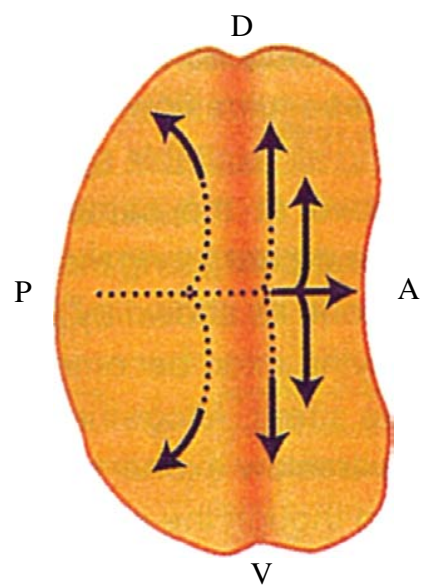

Figure 10. Pattern formation in the developing eye disc in Drosophila: D, dorsal; V, ventral; A, anterior; P, posterior. Adapted from Jaffe (1999, fig. 5A).
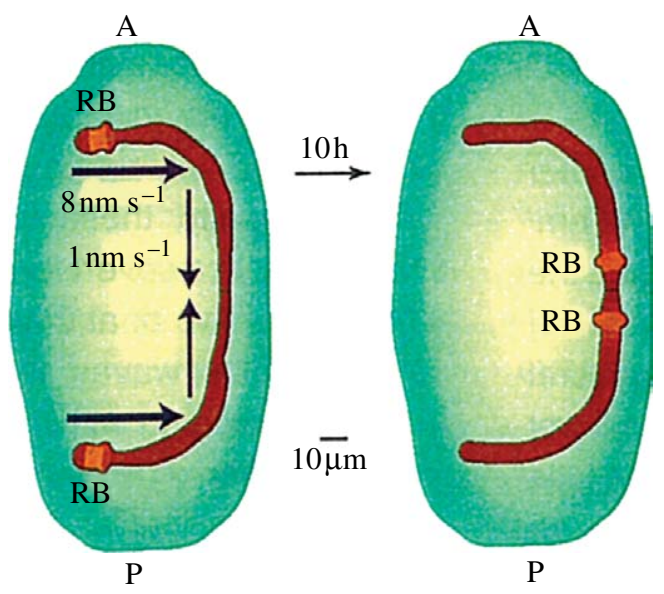

Figure 11. Movement of the DNA replication band (RB) along the macronucleus of the developing ciliate, Euplotes: A, anterior; P, posterior. Adapted from Jaffe (1999, fig. 5B).

move so slowly that high spatial resolution can be exchanged for low temporal resolution in their study with aequorins.

The author wishes to thank John Furfey for ushering him into twenty-first century use of the computer and Michael Whitaker for inviting him to talk at the recent meeting of the Royal Society on 'Calcium signals and developmental patterning'. 

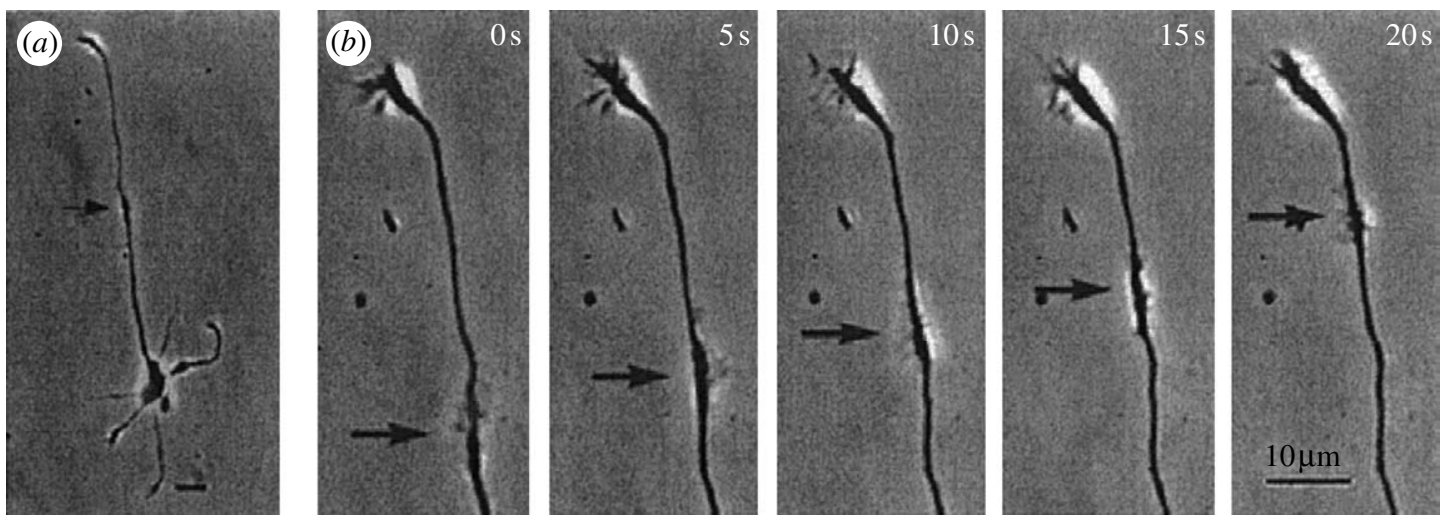

Figure 12. Wave of protrusion of a structure that resembles a growth cone that was recently isolated from embryonic rat hippocampi. Adapted from Ruthel \& Banker (1998, fig. 1b).

Table 2. A list of ultraslow waves that may be morphogenetic. (Note that these speeds are in $\mathrm{nm} \mathrm{s}^{-1}$ rather than $\mu \mathrm{m} \mathrm{s}^{-1}$.)

\begin{tabular}{|c|c|c|c|}
\hline no & system & indicator & speed $\left(\mathrm{nm} \mathrm{s}^{-1}\right)$ \\
\hline 1 & Candida albicans (Dujardin \& Walbaum 1985) & spore formation & 8 \\
\hline 2 & Volvox Rouselleti (Pockock 1933) & inversion & 10 \\
\hline 3 & V. aureus (Kelland 1977, fig. 9) & inversion & 10 \\
\hline 4 & V. carteri $^{\mathrm{a}}$ (Viamontes \& Kirk 1977) & inversion & 15 \\
\hline \multirow{2}{*}{5} & Drosophila eye disc ( Tio et al. 1996) & furrowing forward & 1 \\
\hline & Drosophila eye disc ( Tio et al. 1996) & furrowing sideways & 6 \\
\hline 6 & axolotl embryo (Brodland et al. 1994) & $\begin{array}{l}\text { furrowing during neural } \\
\text { induction }\end{array}$ & 50 \\
\hline 7 & axolotl embryo (Armstrong \& Graveson 1988), figure 5 & somite segmentation & 15 \\
\hline 8 & sunflower & floret formation & $3^{\mathrm{a}}$ \\
\hline \multirow[t]{3}{*}{9} & Euplotes (a ciliate) macronucleus (Ringertz \& Hoskins 1965), figure 11 & DNA replication & \\
\hline & Euplotes (a ciliate) macronucleus (Ringertz \& Hoskins 1965), figure 11 & DNA replication early & 1 \\
\hline & Euplotes (a ciliate) macronucleus (Ringertz \& Hoskins 1965), figure 11 & DNA replication late & 8 \\
\hline 10 & leech embryo axons (Braun \& Stent 1989) & elongation rate & 4 \\
\hline 11 & rat embryonic hippocampal axons (Ruthel \& Banker 1998), figure 12 & growth cone formation & 14 \\
\hline
\end{tabular}

a This figure was obtained by multiplying the formation of 4-5 floret rings per day under optimal conditions (Palmer 1996) by a ring width of $110 \mu \mathrm{m}$ (Hernandez \& Green 1993).

\section{REFERENCES}

Agrell, I. 1962 Mitotic gradients in the early insect embryo. Ark. Zool. 15, 143-149.

Antoine, A. F., Faure, J.-E., Cordeiro, S., Dumas, C., Rougier, M. \& Feijo, J. A. 2000 A calcium influx is triggered and propagates in the zygote as a wavefront during in vitro fertilization of flowering plants. Proc. Natl Acad. Sci. USA 97, 10 643-10 648. (doi:10.1073/pnas.180243697)

Arikawa, M., Momokawa, N., Saito, A., Omura, G., Khan, S. M. M. K., Suetomo, Y., Kakuta, S. \& Suzaki, T. 2003 $\mathrm{Ca}^{2+}$-dependent contractility of isolated and demembranated macronuclei in the hypotrichous ciliate Euplotes aediculatus. Cell Calcium 33, 113-117. (doi:10.1016/ S0143-4160(02)00204-X)

Armstrong, J. B. \& Graveson, A. C. 1988 Progressive patterning precedes somite segmentation in the Mexican axolotl (Ambystoma mexicanum). Dev. Biol. 126, 1-6. (doi:10.1016/0012-1606(88)90232-1)

Beloussov, L. V., Labas, J. A., Kazakova, N. I. \& Zaraiski, A. G. 1989 Cytophysiology of growth pulsations in hydroid polyps. f. Exp. Zool. 249, 258-270. (doi:10.1002/jez.1402490304)

Bonner, J. T. 1998 A way of following individual cells in the migrating slugs of Dictyostelium discoideum. Proc. Natl Acad. Sci. USA 95, 9355-9359. (doi:10.1073/pnas.95.16.9355)

Braun, J. \& Stent, G. S. 1989 Axon outgrowth along segmental nerves in the leech. Dev. Biol. 132, 471-485. (doi:10.1016/0012-1606(89)90243-1)
Bretschneider, T., Diez, S. K., Anderson, K., Heuser, J., Clarke, M., Muller-Taubenberger, A., Kohler, J. \& Gerisch, G. 2004 Dynamic actin patterns and Arp2/3 assembly at the substrate-attached surface of motile cells. Curr. Biol. 14, 1-10. (doi:10.1016/j.cub.2003.12.005)

Brodland, G. W. et al. 1994 Furrowing surface contraction wave coincident with primary neural induction in amphibian embryos. F. Morphol. 219, 131-142. (doi:10. 1002/jmor.1052190203)

Cosens, B., Thacker, D. \& Brimijoin, S. 1976 Temperaturedependence of rapid axonal transport in sympathetic nerves of the rabbit. F. Neurobiol. 7, 339-354. (doi:10. 1002/neu.480070406)

Créton, R., Speksnijder, J. E. \& Jaffe, L. F. 1998 Patterns of free calcium in zebrafish embryos. F. Cell Sci. 111, 1613-1622.

Créton, R., Kreiling, J. A. \& Jaffe, L. F. 1999 Calcium imaging with chemiluminescence. Microsc. Res. Technol. 46, 390-397. (doi:10.1002/(SICI) 1097-0029(19990915) 46:6<390::AID-JEMT7>3.0.CO;2-S)

Dan, K. 1960 Cyto-embryology of echinoderms and amphibia. Int. Rev. Cytol. 9, 321-367.

Digonnet, C., Aldon, D., Leduc, N., Dumas, C. \& Rougier, M. 1997 First evidence of a calcium transient in flowering plants at fertilization. Development 124, 2867-2874.

Dormann, D. \& Weijer, C. J. 2001 Propagating chemotractant waves coordinate periodic cell movement in Dictyostelium slugs. Development 128, 4535-4543. 
Dujardin, L. \& Walbaum, S. 1985 Apport de la théorie des catastrophes à la description de la morphogenèsis de Candida albicans. Physiol. Vég. 23, 309-320.

Fernandez, J., Olea, N., Tellez, V. \& Matte, C. 1990 Structure and development of the egg of the glossiphoniid leech Theromyzon rude: reorganization of the fertilized egg during completion of the first meiotic division. Dev. Biol. 137, 142-154. (doi:10.1016/0012-1606(90)90015-B)

Fluck, R. A., Miller, A. L. \& Jaffe, L. F. 1991 Slow calcium waves accompany cytokinesis in medaka fish eggs. F. Cell Biol. 115, 1259-1265. (doi:10.1083/jcb.115.5.1259)

Foe, V. E. \& Alberts, B. M. 1983 Studies of nuclear and cytoplasmic behavior during the five mitotic cycles that precede gastrulation in Drosophila embryogenesis. F. Cell Sci. 61, 31-70.

Futrelle, R. P., Traut, J. \& McKee, G. 1982 Cell behavior in Dictyostelium discoideum: preaggregation response to localized cyclic AMP pulses. F. Cell Biol. 92, 807-821. (doi:10. $1083 /$ jcb.92.3.807)

Gilkey, J. G., Jaffe, L. F., Ridgway, E. B. \& Reynolds, G. T. 1978 A free calcium wave traverses the activating egg of the medaka, Oryzias latipes. F. Cell Biol. 76, 448-466. (doi:10.1083/jcb.76.2.448)

Hernandez, L. F. \& Green, P. B. 1993 Transductions for the expression of structural pattern: analysis in sunflower. Plant Cell 5, 1725-1738. (doi:10.1105/tpc.5.12.1725)

Houliston, E., Carre, D., Johnston, J. A. \& Sardet, C. 1993 Axis establishment and microtubule-mediated waves prior to first cleavage in Beroe ovata. Development 117, 75-87.

Jaffe, L. F. 1991 The path of calcium in cytosolic calcium oscillations: a unifying hypothesis. Proc. Natl Acad. Sci. USA 88, 9883-9887. (doi:10.1073/pnas.88.21.9883)

Jaffe, L. F. 1997 Chapter 19. In The roles of calcium in pattern formation (eds Y. Maeda, K. Inouye \& I. Takeuchi), pp. 267-277. Tokyo, Japan: Academic Press.

Jaffe, L. F. 1999 Organization of early development by calcium patterns. BioEssays 21, 657-667. (doi:10.1002/(SICI)15211878(199908)21:8<657::AID-BIES5 > 3.0.CO;2-K)

Jaffe, L. F. 2002 On the conservation of fast calcium wave speeds. Cell Calcium 32, 217-229. (doi:10.1016/ S0143416002001574)

Jaffe, L. F. \& Créton, R. 1998 On the conservation of calcium wave speeds. Cell Calcium 24, 1-8. (doi:10.1016/S01434160(98)90083-5)

Kam, Z., Minden, J. S., Agard, D. A., Sedat, J. W. \& Leptin, M. 1991 Drosophila gastrulation: analysis of cell shape changes in living embryos by three-dimensional fluorescene microscopy. Development 112, 365-370.

Kelland, J. L. 1977 Inversion in Volvox (Chlorophyceae). f. Phycol. 13, 373-378.

Lewis, C. A., Chia II, F. S. \& Schroeder, T. E. 1973 Peristaltic constrictions in fertilized barnacle eggs (Pollicipes polymerus). Experientia 29, 1533-1555. (doi:10.1007/ BF01943901)

Malhó, R. \& Trewavas, A. J. 1996 Localized apical increases of cytosolic free calcium control pollen tube orientation. Plant Cell 8, 1935-1949. (doi:10.1105/tpc.8.11.1935)

Miyamoto, D. \& van der Meer, J. M. 1982 Early egg contractions and patterned parasynchronous cleavage in a living insect egg. Wilhelm Roux Archiv. 191, 95-102. (doi:10.1007/BF00848446)

Muto, A., Kume, S., Inoue, T., Okano, H. \& Mikoshiba, K. 1996 Calcium waves along the cleavage furrows in cleavagestage Xenopus embryos and its inhibition by heparin. F. Cell Biol. 135, 181-190. (doi:10.1083/jcb.135.1.181)

Nishii, I. \& Ogihara, S. 1999 Actomyosin contraction of the posterior hemisphere is required for inversion of the Volvox embryo. Development 126, 2117-2127.
Nishii, I., Ogihara, S. \& Kirk, D. L. 2003 A kinesin, InvA, plays an essential role in Volvox morphogenesis. Cell 113, 743-753. (doi:10.1016/S0092-8674(03)00431-8)

Palmer, J. H. 1996 Floret initiation and production in the oil-seed sunflower. In Proc. Intercompositae Conf. Kew Gardens 1994, vol. 2 (eds D. J. N. Hind, H. J. Beentje \& P. D. S. Caligari), pp. 161-178. Kew, UK: Kew Publishing.

Pockock, M. A. 1933 Volvox in South Africa. Ann. S. Afr. Mus. 16, 523-646.

Rietdorf, J. F., Siegert, F. \& Weijer, C. 1996 Analysis of optical density wave propagation and movement during mound formation in Dictyostelium discoideum. Dev. Biol. 177, 427-438. (doi:10.1006/dbio.1996.0175)

Rieu, J.-P., Barentin, C., Sawai, S., Maeda, Y. \& Sawada, Y. 2004 Cell movements and mechanical force distribution during the migration of Dictyostelium slugs. F. Biol. Phys. 30, 345-364. (doi:10.1007/s10867-004-0783-y)

Ringertz, N. R. \& Hoskins, G. C. 1965 Cytochemistry of macronuclear reorganization. Exp. Cell Res. 38, 160-179. (doi:10.1016/0014-4827(65)90438-6)

Robertson, A. 1979 Waves propagated during vertebrate development: observations and comments. F. Embryol. Exp. Morphol. 50, 155-167.

Ruthel, G. \& Banker, G. 1998 Actin-dependent anterograde movement of growth-cone-like structures along hippocampal axons: a novel form of axonal transport? Cell Motil. Cytoskeleton 40, 160-173. (doi:10.1002/(SICI) 1097-0169(1998)40:2<160::AID-CM5 > 3.0.CO;2-J)

Sardet, C., Speksnijder, J., Inoue, S. \& Jaffe, L. 1989 Fertilization and ooplasmic movements in the ascidian egg. Development 105, 237-249.

Savage, R. M. \& Danilchik, M. V. 1993 Dynamics of germ plasm localization and its inhibition by ultraviolet irradiation in early cleavage Xenopus embryos. Dev. Biol. 157, 371-382. (doi:10.1006/dbio.1993.1142)

Selman, G. G. \& Waddington, C. H. 1955 The mechanism of cell division in the cleavage of the newt's egg. F. Exp. Biol. 32, 700-733.

Simon, J. Z. \& Cooper, M. S. 1995 Calcium oscillations and calcium waves coordinate rhythmic contractile activity within the stellate cell layer of medaka fish embryos. f. Exp. Zool. 273, 118-129. (doi:10.1002/jez.1402730205)

Stern, C. D. \& Goodwin, B. C. 1977 Waves and periodic events during primitive streak formation in the chick. 7. Embryol. Exp. Morphol. 41, 15-22.

Tam, S. L. \& Gordon, T. 2003 Mechanisms controlling axonal sprouting at the neuromuscular junction. F. Neurocytol. 32, 961-974. (doi:10.1023/B:NEUR.000 $0020635.41233 .0 \mathrm{f})$

Tio, M., Ma, C. \& Moses, K. 1996 Extracellular regulators and pattern formation in the developing Drosophila retina. Biochem. Soc. Symp. 62, 61-75.

Tucker, E. B., Lee, M., Alli, S., Sookhdeo, V., Wada, M., Imaizumi, T. \& Kasahara, M. 2005 UV-A induces two calcium waves in Physcomitrella patens. Plant Cell Physiol. 46, 1226-1236. (doi:10.1093/pcp/pci131)

Viamontes, G. I. \& Kirk, D. L. 1977 Cell shape changes and the mechanism of inversion in Volvox. F. Cell Biol. 75, 719-730. (doi:10.1083/jcb.75.3.719)

Vollmar, H. 1972 Die Einrollbewegung (Anatrepsis) des Keimstreifs im Ei von Acheta domesticus (Orthopteridea, Gryllidae). Wilhelm Roux Arch. 170, 135-151. (doi:10. 1007/BF00577013)

Wolf, R. 1985 Migration and division of cleavage nuclei in the gall midge Wachtliella persicariae. Wilhelm Roux Archiv 194, 257-270. (doi:10.1007/BF01152171) 


\section{NOTICE OF CORRECTION}

Paragraph $2 \S 1$, the final paragraph of $\S 2$, paragraph 3 of $\S 3$ and table 1 are now presented in the correct form.

25 January 2008 